\title{
Karakteristik Mutu, Organoleptik Dan Aktivitas Antibakteri Sabun Padat Transparan Dengan Penambahan Minyak Serai Wangi (Cymbopogon nardus L) \\ (Quality Characteristic, Organoleptic and Antibacterial Activity of Transparent Solid Soap with Addition of Citronella Oil (Cymbopogon nardus L))
}

\author{
Ova Ariska ${ }^{1}$, Bahlina Mohd. Nur ${ }^{1}$, Yuliani Aisyah ${ }^{1 *}$ \\ ${ }^{1}$ Program Studi Teknologi Hasil Pertanian, Fakultas Pertanian, Universitas Syiah Kuala
}

\begin{abstract}
Abstrak. Tanaman serai wangi (Cymbopogon nardus L) merupakan salah satu jenis tanaman wewangian yang memiliki kandungan minyak atsiri yang dapat digunakan sebagai agen antibakteri. Melihat potensi antibakteri yang dimiliki minyak serai wangi, menarik untuk diformulasikan dalam suatu sediaan seperti sabun mandi sehingga dapat membantu meningkatkan nilai guna dari sabun. Penelitian ini menggunakan rancangan acak lengkap (RAL) dengan pola non faktorial yang terdiri dari 7 taraf dan 3 ulangan, yaitu konsentrasi minyak serai wangi 0 (M1), 0,5\% (M2), $1 \%$ (M3), 1,5\% (M4), 2\% (M5), 2,5\% (M6) dan 3\% (M7). Analisis terhadap sabun padat transparan yang dilakukan meliputi analisis kimia (kadar air, alkali bebas dan $\mathrm{pH}$ ), uji aktivitas antibakteri terhadap bakteri Staphylococcus aureus serta uji organoleptik secara hedonik (warna, aroma, kekerasan, transparansi, banyak busa dan after used). Hasil penelitian menunjukkan penambahan konsentrasi minyak serai wangi pada pembuatan sabun padat transparan berpengaruh sangat nyata $(\mathrm{P} \leq 0,01)$ terhadap kadar air, alkali bebas dan $\mathrm{pH}$. Sabun padat transparan tersebut memiliki nilai kadar air 2,61-5,67\%, kadar alkali bebas $0,12-0,36 \%$ dan nilai $\mathrm{pH} 11,14-11,42$. Hasil uji ktivitas antibakteri menunjukan sabun padat transparan minyak serai wangi mampu menghambat bakteri Staphylococcus aureus sebesar 1,64 mm pada penambahan minyak serai wangi dengan konsentrasi 2,5\%. Namun, hasil uji organoleptik menunjukkan bahwa penambahan minyak serai wangi pada pembuatan sabun padat transparan minyak serai wangi tidak berpengaruh nyata $(\mathrm{P}>0,05)$ terhadap hedonik warna, aroma, kekerasan, transparansi, banyak busa dan after used yang dilakukan dengan metode hedonik. Sabun padat transparan dengan penambahan minyak serai wangi 2,5\% merupakan perlakuan terbaik yang ditentukan berdasarkan hasil uji aktivitas antibakteri.
\end{abstract}

Kata kunci: Sabun padat transparan, mutu, antibakteri, serai wangi

Abstract. Citronella plant (Cymbopogon nardus L) is a type of fragrance plant that contains essential oils that can be used as antibacterial agents. Seeing the antibacterial potential of lemongrass oil, it is interesting to formulate it in a preparation such as bath soap so that it can help increase the useful value of soap. This study used a completely randomized design (CRD) with a non-factorial pattern consisting of 7 levels and 3 replications, namely the concentration of citronella oil 0 (M1), $0.5 \%$ (M2), $1 \%$ (M3), 1.5\%. (M4), 2\% (M5), 2.5\% (M6) and $3 \%$ (M7). The analysis of transparent solid soap includes chemical analysis (moisture content, free alkali and $\mathrm{pH}$ ), antibacterial activity test against Staphylococcus aureus bacteria and hedonic organoleptic tests (color, aroma, hardness, transparency, lots of foam and after use). The results showed that the addition of citronella oil concentration in the manufacture of transparent solid soap had a very significant effect $(\mathrm{P} \leq 0.01)$ on water content, free alkalis and $\mathrm{pH}$. The transparent solid soap has a moisture content value of $2.61-5.67 \%$, a free alkaline content of $0.12-0.36 \%$ and a $\mathrm{pH}$ value of $11.14-11.42$. The results of the antibacterial activity test showed that the transparent solid soap of citronella oil was able to inhibit Staphylococcus aureus bacteria by $1.64 \mathrm{~mm}$ in the addition of citronella oil with a concentration of $2.5 \%$. However, the results of the organoleptic test showed that the addition of citronella oil to the manufacture of transparent solid citronella oil had no significant effect (P> 0.05) on hedonic color, aroma, hardness, transparency, lots of foam and after use which was carried out using the hedonic method. Transparent solid soap with the addition of $2.5 \%$ citronella oil is the best treatment determined based on the results of the antibacterial activity test.

Keywords: Transparent solid soap, quality, antibacterial, citronella oil

\section{PENDAHULUAN}

Sabun dihasilkan dari proses saponifikasi, yaitu hidrolisis lemak menjadi asam lemak dan gliserol dalam kondisi basa. Kondisi basa diperoleh dari $\mathrm{NaOH}$ atau $\mathrm{KOH}$. Asam lemak yang berikatan dengan natrium atau kalium inilah yang kemudian dinamakan sabun, sehingga

Corresponding author: yuliani.aisyah@unsyiah.ac.id

JIM Pertanian - THP, Vol. 6, No. 1, Februari 2021: 27-36 
sabun dikatakan sebagai salah satu garam basa dari berbagai lemak (Hernani dkk., 2010). Berdasarkan jenisnya, sabun dibedakan atas dua macam yaitu sabun padat (batang) dan sabun cair.

Sabun transparan menjadi pilihan konseumen karena menjadi salah satu produk kecantikan, menghasilkan busa yang lebih lembut dan dapat digunakan untuk merawat kulit karena mengandung bahan-bahan yang berfungsi sebagai humektan (moisturizer). Saat ini sabun transparan banyak diproduksi dengan penambahan bahan-bahan alami dan sangat diminati oleh konsumen, terutama yang bermanfaat untuk kesehatan tubuh, misalnya sabun yang ditambahkan senyawa atau bahan yang berfungsi sebagai antibakteri. Penggunaan antibakteri yang berasal dari bahan alami merupakan salah satu alternatif untuk menghindari terjadinya efek samping yang mungkin ditimbulkan dari penggunaan bahan-bahan berbahaya. Penggunaan bahan-bahan alami bertujuan untuk menggantikan fungsi dari bahan-bahan sintetik, seperti parfum, pewarna, pemutih, antibakteri dan lain-lain. Beberapa peneliti telah melakukan pembuatan sabun antibakteri dengan penambahan bahan-bahan alami sebagai antibakteri seperti ekstrak daun jati (Tectona Grandis L.F) (Juniarti, dkk., 2017), ekstrak teh putih (Camellia sinensis) (Widyasanti, dkk., 2016), dan ekstrak lengkuas (Alpinia galangal L.Swartz) (Hernani, dkk., 2010).

Menurut Luangnarumitchai (2007), minyak atsiri serai wangi merupakan salah satu minyak atsiri yang memiliki aktivitas antibakteri terbesar. Berdasarkan penelitian yang dilakukan oleh Paramita dkk (2014) diketahui bahwa minyak atsiri serai wangi memiliki aktivitas antibakteri terhadap bakteri Staphylococcus aureus pada konsentrasi 0,8\% dengan zona hambat sebesar $4,77 \mathrm{~mm}$. Selain memiliki aktivitas antibakteri terhadap bakteri Staphylococcus aureus, minyak serai wangi juga terbukti dapat menghambat bakteri lain seperti Escherichia coli, Bacillus cereus, Bacillus subtilis dan Pseudomonas aeruginos (Naik dkk., 2010). Menurut Onawunmit dkk (1984) bakteri Gram positif diketahui akan lebih sensitif terhadap minyak atsiri serai wangi dibandingkan dengan Gram negatif.

Minyak atsiri serai wangi memiliki aktivitas antibakteri hal ini dikarenakan pada minyak serai wangi terdapat senyawa aktif yaitu sitronelal (Agustian dkk, 2007). Selain sitronelal senyawa lain yang terdapat pada minyak atsiri serai wangi yaitu geraniol (Suprianto, 2008). Minyak serai wangi juga mengandung senyawa aktif lainnya seperti saponin, alkaloid, flavonoid, dan polifenol. Senyawa flavonoid dan saponin yang diketahui mempunyai aktivitas antibakteri. Melihat potensi antibakteri yang dimiliki minyak atsiri serai wangi, menarik untuk diformulasikan dalam suatu sediaan seperti sabun padat transparan, sehingga dapat membantu meningkatkan nilai guna dari sabun tersebut.

\section{METODE PENELITIAN}

Penelitian ini dilaksanakan di Laboratorium Analisis Pangan dan Hasil Pertanian, Laboratorium Mikrobiologi Pangan dan Industri dan Laboratorium Uji Sensori di Jurusan Teknologi Hasil Pertanian Fakultas Pertanian Universitas Syiah Kuala.

\section{BAHAN DAN METODE}

\section{Bahan dan Alat}

Bahan-bahan yang digunakan pada pembuatan sabun padat transparan yaitu minyak serai wangi yang didapat dari PT. Djasula Wangi Kemayoran Jakarta Pusat DKI Jakarta, minyak sawit (merek Bimoli), asam stearat, $\mathrm{NaOH}$, etanol, gula pasir, gliserin, Coco-Dea, $\mathrm{NaCl}$, 
aquades. $\mathrm{HCl}$. Sedangkan bahan yang digunakan untuk analisis mutu dan uji aktivitas antibakteri sabun padat transparan yaitu indikator phenoplpthalein, $\mathrm{H}_{2} \mathrm{SO}_{4}$, methyl orange, $\mathrm{KOH}$ dan media MHA (Mueller Hiton Agar).

Alat-alat yang digunakan pada pembuatan sabun padat transparan yaitu hot plate, timbangan analitik, gelas beaker, spatula, termometer, pipet tetes dan gelas ukur. Sedangkan alat yang digunakan pada analisis mutu dan aktivitas antibakteri sabun padat transparan yaitu hot plate, gelas beaker, oven, labu pemisah, $\mathrm{pH}$ meter, alat titrasi, desikator, cawan petri, erlemeyer dan kertas cakram.

\section{Metode Penelitian}

Penelitian ini menggunakan rancangan acak lengkap (RAL) pola non faktorial dengan faktor konsentrasi minyak serai wangi yang terdiri dari 7 taraf yaitu $0 \%(\mathrm{M} 1), 0,5 \%$ (M2), $1 \%$ (M3), 1,5\% (M4), 2\% (M5), 2,5\% (M6) dan 3\% (M7). Setiap perlakuan dilakukan pengulangan sebanyak 3 kali, sehingga seluruh total satuan percobaan yang akan dilakukan sebanyak 21 satuan percobaan. Apabila hasil ANOVA berpengaruh nyata, maka dilakukan uji lanjut yaitu menggunakan metode Duncan Multiple Range -Test (DMRT)

\section{Prosedur Pembuatan Sabun}

Adapun cara pembuatan sabun padat transparan pada penelitian ini yaitu bahan ditimbang sesuai perlakuan. Asam stearat sebanyak $14 \mathrm{~g}$ dimasukkan kedalam beaker glass dan dipanaskan menggunakan hot plate selama 2 menit hingga mencair. Selanjutnya ditambahkan minyak goreng kelapa sawit sebanyak $40 \mathrm{~g}$ dan dilakukan pemanasan pada suhu $70^{\circ} \mathrm{C}$, setelah larutan homogen ditambahkan $\mathrm{NaOH}$ sebanyak 40,6 g, diaduk menggunakan spatula hingga homogen dan terbentuk stok sabun atau sabun dasar. Gliserin sebanyak $26 \mathrm{~g}$ dan etanol sebanyak 30 g kemudian ditambahkan kedalam stok sabun, suhu pada tahap ini dijaga antara $70-80^{\circ} \mathrm{C}$. Kemudian masukkan bahan lainnya seperti sukrosa sebanyak $34 \mathrm{~g}$, Coco-Dea sebanyak $6 \mathrm{~g}, \mathrm{NaCl}$ sebanyak $0,4 \mathrm{~g}$ dan aquadest sebanyak $9 \mathrm{~g}$ kemudian ditambahkan dan pemanasan tetap terus dilakukan pada suhu $70-80^{\circ} \mathrm{C}$ selama 30 menit atau hingga semua bahan larut (homogen). Setelah bahan larut dengan sempurna, larutan sabun diturunkan suhunya hingga mencapai $40^{\circ} \mathrm{C}$ dengan cara menghentikan proses pemanasan. Kemudian dimasukkan minyak serai wangi dengan konsentrasi yang sudah ditentukan $(0 \%, 0,5 \%, 1 \%, 1,5 \%, 2 \%$, $2,5 \%, 3 \%$ ). Dilakukan pengadukan hingga minyak serai wangi tercampur rata dan dilakukan pencetakan. Sabun kemudian dibiarkan hingga mengeras selama 30 menit dan dilakukan curing selama tiga minggu sebelum dianalisis.

\section{Analisis Karakteristik Sabun Padat Transparan}

Analisis yang akan dilakukan pada penelitian ini adalah pengujian alkali bebas (Ayu dkk., 2018), kadar air (SNI 3532-2016), pH (Ayu dkk., 2018), uji aktivitas antibakteri (Ayu dkk., 2018) dan uji organoleptik secara hedonik (SNI 01-2346-2006).

\section{HASIL DAN PEMBAHASAN}

Sabun padat transparan dengan penambahan minyak serai wangi yang di hasilkan di dalam penelitian ini dilakukan pengujian karakteristik mutu (kadar air, alkali bebas, dan $\mathrm{pH}$ ), karakteristik organoleptik secara hedonik (tekstur, warna, aroma, busa, transparansi), dan uji aktivitas antibakteri terhadap bakteri Staphylococcus aureus. Adapun sabun padat transparan yang dihasilkan dapat dilihat pada Gambar 1.

Karakteristik Mutu, Organoleptik Dan Aktivitas Antibakteri Sabun Padat Transparan Dengan Penambahan Minyak Serai Wangi (Cymbopogon nardus L) (Ova Ariska, Bahlina Mohd. Nur, Yuliani Aisyah) 


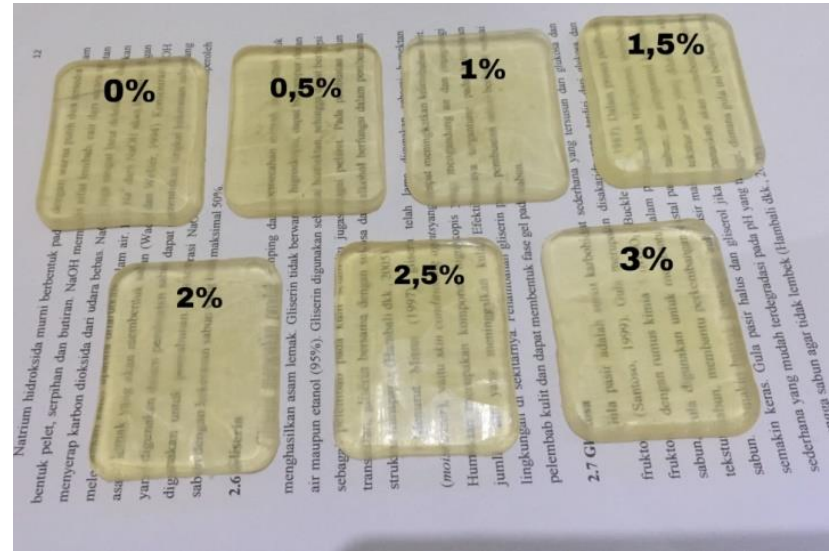

Gambar 1 Sabun Padat Transparan Minyak Serai Wangi

\section{Alkali Bebas}

Nilai alkali bebas sabun padat transparan pada penelitian ini berkisar antara $0,12 \%$ hingga 0,36\% dengan nilai rata-rata sebesar 0,22\%. Berdasarkan hasil Analysis of Variance (ANOVA) menunjukkan bahwa konsentrasi minyak serai wangi $(M)$ berpengaruh sangat nyata $(\mathrm{P} \leq 0,01)$ terhadap alkali bebas sabun padat transparan yang dihasilkan. Adapun grafik yang menunjukkan pengaruh konsentrasi minyak serai wangi terhadap nilai alkali bebas sabun padat transparan dapat dilihat pada Gambar 2.

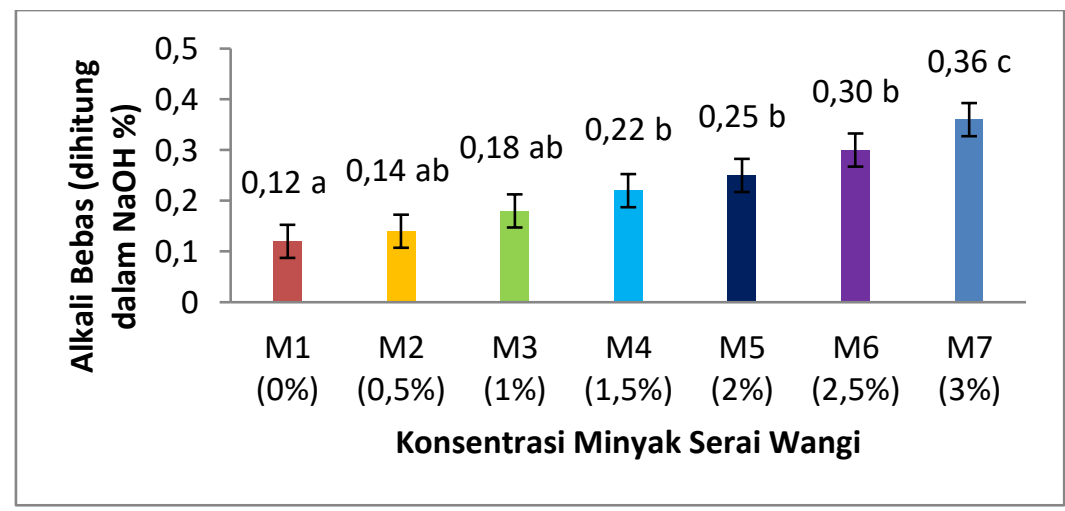

Gambar 2. Pengaruh Konsentrasi Minyak Serai Wangi Terhadap Alkali Bebas Sabun Padat Transparan Pada Uji Lanjut DMRT 0,05 $=0,059, \mathrm{KK}=1,916 \%$ (Nilai yang diikuti dengan huruf yang sama menunjukkan perbedaan yang tidak nyata).

Pada Gambar 2 dapat dilihat bahwa nilai alkali bebas sabun tertinggi diperoleh pada sabun dengan konsentrasi minyak serai wangi sebesar 3\% yaitu $0,36 \%$. Menurut Ketaren (1985), minyak serai wangi mengandung senyawa sitronelal yang memiliki persentase tertinggi (32-45\%), diikuti dengan geraniol $12-18 \%$ dan sitronelol $12-15 \%$, dibandingkan dengan senyawa-senyawa lain yang terdapat di dalam minyak serai wangi. Sitronelol atau sering juga disebut dengan hidrogeraniol adalah suatu monoterpena alami dengan rumus molekul $\mathrm{C}_{10} \mathrm{H}_{20} \mathrm{O}$ yang diperoleh dari minyak serai wangi. Dalam perdagangan, sitronelol diperoleh dengan mereduksi sitronenal yang terdapat dalam minyak serai wangi (Agustian, 2007). Meningkatnya kadar alkali bebas di dalam sabun padat transparan yang dihasilkan diduga karena $\mathrm{OH}$ dari sitronelol dan geraniol berikatan dengan $\mathrm{Na}$ dari $\mathrm{NaOH}$ yang digunakan di dalam pembuatan sabun padat transparan, sehingga meningkatkan kadar alkali bebas dari sabun padat transparan.

Karakteristik Mutu, Organoleptik Dan Aktivitas Antibakteri Sabun Padat Transparan Dengan Penambahan Minyak Serai Wangi (Cymbopogon nardus L) (Ova Ariska, Bahlina Mohd. Nur, Yuliani Aisyah) 
Semakin tinggi konsentrasi minyak serai wangi pada pembuatan sabun maka kadar alkali bebas semakin meningkat.

Hasim dkk, (2015), melaporkan bahwa minyak serai wangi mengandung senyawa alkaloid yang bersifat basa. Senyawa basa yang terdapat pada minyak serai wangi menyebabkan dibutuhkan senyawa asam lemak tambahan untuk dapat mengikat seluruh alkali sehingga dapat mencegah adanya alkali bebas yang terkandung pada sabun. Menurut Lenny (2006) senyawa alkaloid diduga menyebabkan nilai kadar alkali bebas bertambah karena senyawa alkaloid memiliki sifat yang basa / alkali. Menurut Karo (2011), faktor yang dapat menyebabkan alkali bebas meningkat karena pada proses pembuatan sabun tidak semua $\mathrm{NaOH}$ berikatan dengan asam lemak dan membentuk sabun.

\section{Kadar Air}

Kadar air sabun padat transparan minyak serai wangi pada penelitian ini berkisar antara $2,61 \%$ hingga $5,67 \%$ dengan rata-rata $4,30 \%$. Berdasarkan hasil Analysis of Variance (ANOVA) menunjukkan bahwa konsentrasi minyak serai wangi (M) berpengaruh sangat nyata $(\mathrm{P} \leq 0,01)$ terhadap kadar air sabun padat transparan yang dihasilkan. Adapun grafik yang menunjukkan pengaruh konsentrasi minyak serai wangi terhadap nilai kadar air sabun padat transparan dapat dilihat pada Gambar 3.

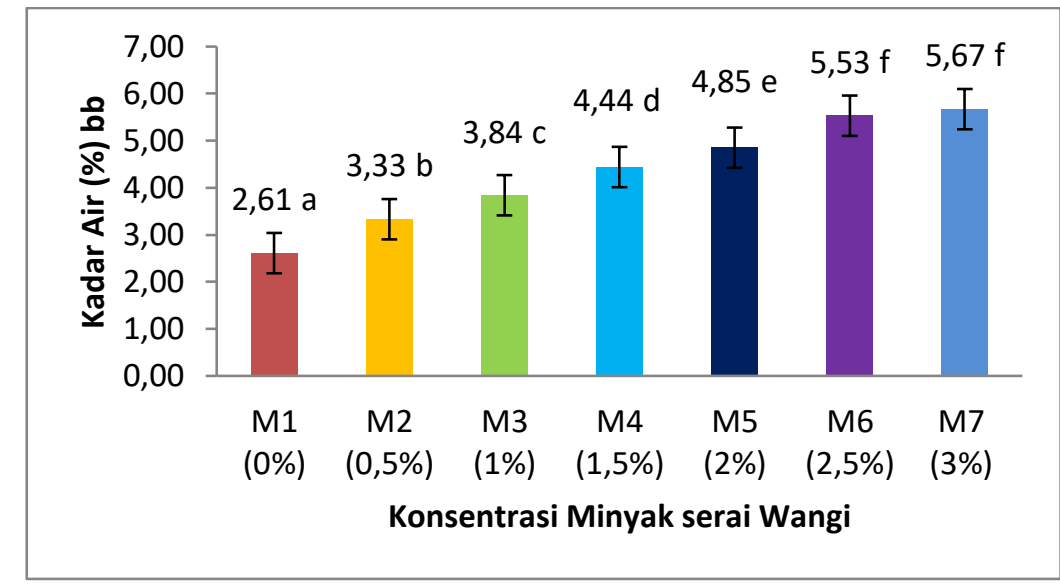

\footnotetext{
Gambar 3. Pengaruh Konsentrasi Minyak Serai Wangi Terhadap Kadar Air Sabun Padat Transparan Pada Uji Lanjut DMRT 0,05 = 0,187, $\mathrm{KK}=0,316 \%$ (Nilai yang diikuti dengan huruf yang sama menunjukkan perbedaan yang tidak nyata).
}

Pada Gambar 3 dapat dilihat bahwa kadar air sabun padat transparan cenderung meningkat seiring dengan semakin meningkat konsentrasi minyak serai wangi yang ditambahkan. Diduga kadar air sabun berasal dari bahan yang digunakan pada proses pembuatan sabun padat transparan yaitu minyak serai wangi dan juga merupakan produk sampingan dari reaksi penyabunan, sehingga semakin banyak penambahan konsentrasi minyak serai wangi yang ditambahkan pada pembuatan sabun padat transparan maka kadar air semakin meningkat. 


\section{pH (Derajat Keasaman)}

Nilai $\mathrm{pH}$ sabun padat transparan minyak serai wangi pada penelitian ini berkisar antara 11,14 hingga 11,42 dengan rata-rata 11,26. Berdasarkan hasil Analysis of Variance (ANOVA) menunjukkan bahwa konsentrasi minyak serai wangi $(M)$ berpengaruh sangat nyata $(P \leq 0,01)$ terhadap $\mathrm{pH}$ sabun yang dihasilkan. Adapun grafik yang menunjukkan pengaruh konsentrasi minyak serai wangi terhadap nilai $\mathrm{pH}$ sabun padat transparan dapat dilihat pada Gambar 4.

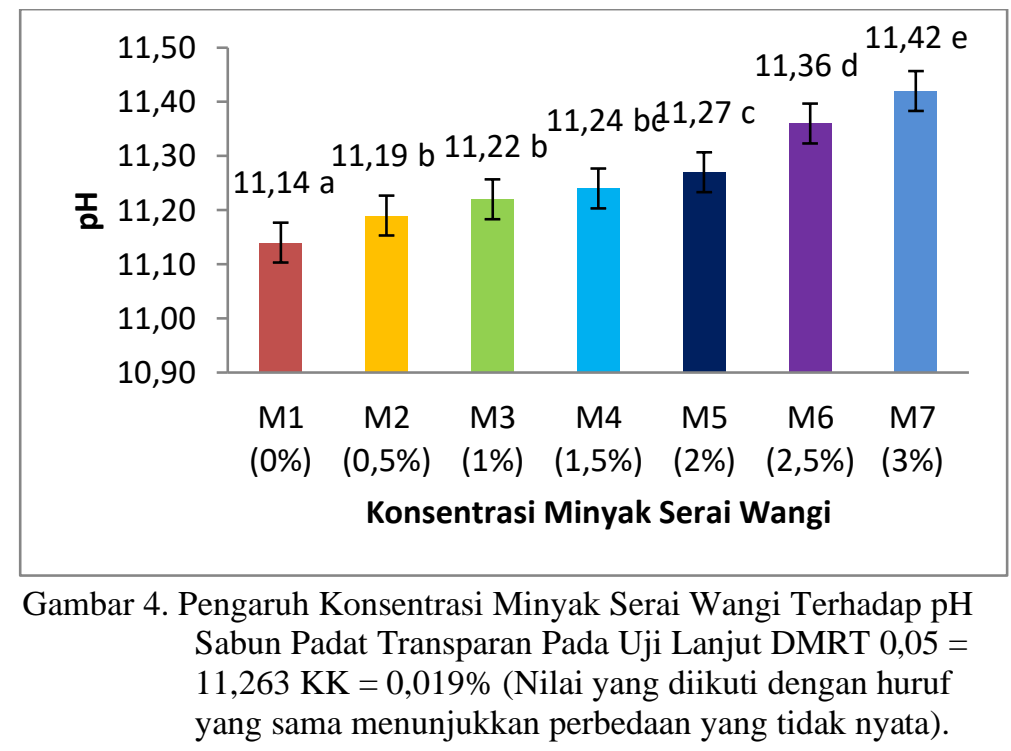

Pada Gambar 4 dapat dilihat bahwa adanya peningkatan nilai $\mathrm{pH}$ sabun seiring dengan semakin meningkat konsentrasi minyak serai wangi yang ditambahkan. Nilai $\mathrm{pH}$ sabun terendah diperoleh pada sabun padat transparan dengan konsentrasi minyak serai wangi $0 \%$ yaitu sebesar 11,14 dan berbeda nyata dengan perlakuan lainnya sedangkan sabun padat transparan dengan nilai $\mathrm{pH}$ tertinggi diperoleh pada sabun dengan konsentrasi minyak serai wangi sebesar 3\% yaitu 11,42. Nilai $\mathrm{pH}$ pada sabun padat transparan memiliki keterkaitan dengan kadar alkali bebas, semakin meningkat kadar alkali bebas pada sabun padat transparan maka nilai $\mathrm{pH}$ pada sabun padat transparan juga semakin tinggi. Meningkatnya nilai $\mathrm{pH}$ pada sabun padat transparan yang dihasilkan diduga karena didalam minyak serai wangi mengandung senyawa sitronelol dan geraniol yang dapat berikatan dengan basa yang digunakan di dalam pembuatan sabun sehingga alkali bebas pada sabun padat transparan meningkat. Selain itu menurut Hasim dkk, (2015), minyak serai wangi juga mengandung alkaloid yang merupakan senyawa organik yang memiliki sifat basa atau alkali (Lenny, 2006).

\section{Aktivitas Antibakteri}

Uji aktivitas antibakteri bertujuan untuk mengetahui kamampuan sabun dalam menghambat pertumbuhan bakteri. Pada penelitian ini uji aktivitas antibakteri dilakukan terhadap sabun dengan konsentrasi minyak serai wangi 0,5\% (M2), 1,5\% (M4) dan 2,5\% (M6). Hasil uji aktivitas antibakteri sabun padat transparan dengan metode difusi dapat dilihat pada Tabel 1. 
Tabel 1. Uji Aktivitas Antibakteri Sabun Padat Transparan Terhadap Bakteri Staphylococcus aureus

\begin{tabular}{lc}
\hline \multicolumn{1}{c}{ Bahan Uji } & Diameter Daya Hambat (mm) \\
\hline $\begin{array}{l}\text { Sabun padat transparan dengan konsentrasi } \\
\text { minyak serai wangi 0,5\% (M2) }\end{array}$ & 0,4 \\
$\begin{array}{l}\text { Sabun padat transparan dengan konsentrasi } \\
\text { minyak serai wangi 1,5\%(M4) }\end{array}$ & 0,98 \\
$\begin{array}{l}\text { Sabun padat transparan dengan konsentrasi } \\
\text { minyak serai wangi 2,5\%(M6) }\end{array}$ & 1,64 \\
$\begin{array}{l}\text { Sabun komersial (Sabun padat opaque / } \\
\text { sabun antibakteri }\end{array}$ & 0,24 \\
\hline
\end{tabular}

Dari Tabel 1 dapat dilihat bahwa sabun padat transparan dengan penambahan minyak serai wangi mampu menghambat bakteri Staphylococcus aureus. Semakin banyak penambahan konsentrasi minyak serai wangi yang ditambahkan pada sabun padat transparan maka diameter daya hambat terhadap Staphylococcus aureus semakin besar. Sabun padat transparan dengan penambahan minyak serai wangi 2,5\% memiliki diameter daya hambat tertinggi yaitu sebesar 1,64 mm dan lebih besar dibandingkan dengan sabun antibakteri komersial. Berdasarkan hasil penelitian Novianti (2017) daya hambat minyak serai wangi terhadap bakteri Staphylococcus aureus pada konsentrasi $20 \%$ memiliki zona hambat sebesar $1,72 \mathrm{~mm}$, sedangkan menurut Riska (2013) sebesar 16,6 mm.

Minyak serai wangi mampu menghambat pertumbuhan bakteri karena senyawa aktif yang terkandung pada minyak serai wangi. Adapun senyawa aktif yang memiliki kemampuan antibakteri yaitu sitronelal $(34,6 \%)$, geraniol $(23,17 \%)$ dan sitronellol $(12,09 \%)$ (Brunegra dkk, 2011). Hasil studi Smic, dkk (2004) menyatakan bahwa komponen sitronellal dan geraniol menunjukkan aktivitas terhadap bakteri Bacillus cereus dan Staphylococcus aureus akan tetapi tidak aktif terhadap bakteri Escherichia coli dan Proteus mirabilis. Selain senyawa sitronelal, geraniol dan sitronelol didalam minyak serai wangi juga mengandung senyawa aktif alkaloid, saponin, tanin, flavonoid, phenol dan steroid. Setiap senyawa tersebut mampu menghambat pertumbuhan bakteri.

\section{Uji Organoleptik}

\section{Warna}

Pengujian warna pada sabun padat transparan dilakukan untuk mengetahui tingkat kesukaan panelis terhadap warna sabun padat transparan yang dihasilkan. Hasil penelitian menunjukkan bahwa warna sabun padat transparan berkisar antara 3,08 (netral) sampai 3,45 (netral) dengan rata-rata 3,28 (netral) (Lampiran 7A). Hasil sidik ragam menunjukkan bahwa konsentrasi minyak serai wangi $(\mathrm{M})$ tidak berpengaruh nyata $(\mathrm{P}>0,05)$ terhadap warna sabun padat transparan (Lampiran 7B). Penambahan minyak serai wangi dengan berbagai konsentrasi tidak mempengaruhi kesukaan penalis terhadap warna sabun padat transparan.

\section{Aroma}

Pengujian aroma pada sabun padat transparan dilakukan untuk mengetahui tingkat kesukaan panelis terhadap aroma sabun padat transparan yang dihasilkan. Hasil penelitian menunjukkan bahwa aroma sabun padat transparan berkisar antara 2,44 (tidak suka) sampai 3,51 (netral) dengan rata-rata 3,04 (netral) (Lampiran 8A). Penambahan minyak serai wangi

Karakteristik Mutu, Organoleptik Dan Aktivitas Antibakteri Sabun Padat Transparan Dengan Penambahan Minyak Serai Wangi (Cymbopogon nardus L) (Ova Ariska, Bahlina Mohd. Nur, Yuliani Aisyah) 
pada sabun padat transparan tidak mempengaruhi kesukaan penelis terhadap aroma sabun padat transparan.

\section{Kekerasan}

Menurut Gusviputri, dkk (2013) kekerasan pada sabun dapat dipengaruhi oleh asam lemak jenuh yang digunakan pada saat pembuatan sabun. Asam lemak jenuh merupakan asam lemak yang tidak memiliki ikatan rangkap dan memiliki titik cair lebih tinggi serta berbentuk padat pada suhu ruang, sehingga akan menghasilkan sabun yang lebih keras. Sabun dengan tekstur lebih keras tidak akan mudah larut dalam air akan tetapi sabun dengan tekstur lebih lunak akan cepat larut dalam air dan cepat rusak.

Uji kekerasan pada sabun padat transparan dilakukan untuk mengetahui kesukaan panelis terhadap kekerasan sabun padat transparan yang dihasilkan. Hasil penelitian menunjukkan bahwa kekerasan sabun padat transparan berkisar antara 2,80 (netral) sampai 3,21 (netral) dengan rata-rata 3,00 (netral) (Lampiran 9A). Hasil sidik ragam menunjukkan bahwa konsentrasi minyak serai wangi $(\mathrm{M})$ tidak berpengaruh nyata $(\mathrm{P}>0,05)$ terhadap kekerasan sabun padat transparan (Lampiran 9A). Penambahan minyak serai wangi pada sabun tidak mempengaruhi kesukaan panelis terhadap kekerasan sabun padat transparan.

\section{Transparansi}

Transparansi sabun padat transparan dapat dipengaruhi oleh bahan tambahan transparent agent seperti penambahan gliserin dan etanol (Rohaeti, 2018). Hasil penelitian menunjukkan bahwa transparansi sabun padat transparan berkisar antara 2,97 (netral) sampai 3,34 (netral) dengan rata-rata 3,22 (netral) (Lampiran 10A). Hasil sidik ragam menunjukkan bahwa konsentrasi minyak serai wangi $(\mathrm{M})$ tidak berpengaruh nyata $(\mathrm{P}>0,05)$ terhadap transparansi sabun padat transparan (Lampiran 10B). Penambahan minyak serai wangi pada sabun tidak mempengaruhi kesukaan panelis terhadap transparansi sabun padat transparan yang di hasilkan.

\section{Banyak Busa}

Hasil penelitian menunjukkan bahwa banyak busa sabun padat transparan berkisar antara 3,02 (netral) sampai 3,38 (netral) dengan rata-rata 3,16 (netral) (Lampiran 11A). Hasil sidik ragam menunjukkan bahwa konsentrasi minyak serai wangi $(\mathrm{M})$ tidak berpengaruh nyata $(\mathrm{P}>0,05 \%)$ terhadap banyak busa sabun padat transparan (Lampiran 11B). Penambahan minyak serai wangi pada sabun tidak mempengaruhi kesukaan panelis terhadap banyak busa sabun padat transparan

\section{After Used}

Hasil penelitian menunjukkan bahwa after used sabun padat transparan berkisar antara 2,81 (netral) sampai 3,11 (netral) dengan rata-rata 2,99 (netral) (Lampiran 12A). Hasil sidik ragam menunjukkan bahwa konsentrasi minyak serai wangi $(\mathrm{M})$ tidak berpengaruh nyata $(\mathrm{P}>0,05)$ terhadap after used sabun padat transparan (Lampiran 12B). Penambahan minyak serai wangi pada sabun tidak mempengaruhi kesukaan panelis terhadap after used sabun padat transparan. 


\section{KESIMPULAN DAN SARAN}

Semakin banyak konsentrasi minyak serai wangi yang ditambahkan pada sabun padat transparan maka semakin meningkat pula nilai kadar air, alkali bebas dan $\mathrm{pH}$ sabun transparan. Penambahan minyak serai wangi pada pembuatan sabun padat transparan tidak berpengaruh nyata $(\mathrm{P}>0,05)$ terhadap hasil uji organoleptik warna, aroma, transparansi, kekerasan, banyak busa dan after used. Penambahan minyak serai wangi menghasilkan sabun yang memiliki efek antibakteri tanpa menimbulkan pengaruh yang negatif terhadap sifat organoleptik sabun padat transparan. Hasil uji aktivitas antibakteri sabun padat transparan minyak serai wangi dengan konsentrasi 2,5\% terhadap bakteri Staphylococcus aureus memiliki diameter daerah hambat lebih besar $(1,64 \mathrm{~mm})$ dibandingkan dengan sabun antibakteri komersial dengan diameter daya hambat sebesar $0,24 \mathrm{~mm}$. Sabun padat transparan dengan penambahan minyak serai wangi 2,5\% merupakan perlakuan terbaik yang ditentukan berdasarkan hasil uji aktivitas antibakteri.

\section{DAFTAR PUSTAKA}

Agustian E., A. T. Sulaswatty., J.A. Laksmon dan B. Adilina. 2007. Pemisahan Sitronelal Dari Minyak Serai Wangi Serai Wangi Menggunakan Unit Fraksionasi Skala Bench. Jurnal Teknologi Industri Pertanian. 17(2): 49-53.

Ayu, D.F., B.S. Nadi dan A. Ali. 2018. Karakteristik dan Aktivitas Antibakteri Minyak Atsiri Rimpang Jerangau (Acruscalamus L) Terhadap Staphylococcus aureus dan Escherichia coli Pada Sabun Transparan. Jurnal Teknologi Industri Pertanian. 28(2): 210-218.

Brugnera, D.F. 2011. Ricotta Microbiological Quality and Use Of Spices in The Control Of Staphylococcus aureus. Disertasi. University of Lavras, Brazil.

Gusviputri, A., Meliana., N.P.S. Aylianawati dan Indraswati, S. 2013. Pembuatan Sabun Dengan Lidah Buaya (Aloe vera) sebagai antiseptik alami. Widya Teknik. 12(1): 11-12.

Ketaren, S. 1985. Pengantar Teknologi Minyak Atsiri. Balai Pustaka. Jakarta.

Hasim, F.S., R. D. Ayunda dan D. N. Faridah. 2015. Potential Of Lemon grass Leaves Extract (Cymbopogon citratus) as Prevention For Oil Oxidation. Journal Of Chemical and Pharmacheutical Research. 7(10): 55-60.

Hernani.,T.K., Bunasor dan Fitriati. 2010. Formula Sabun Transparan Anti jamur dengan Bahan Aktif Ekstrak Lengkuas (AlpiniagalangaL.Swartz.). Bul. Litro. 21(2): 192-205.

Karo, Y.A. 2011. Kajian Pengaruh Penggunaan Kombinasi Jenis Minyak Terhadap Mutu Sabun Transparan. Skripsi. Fakultas Teknologi Pertanian, Institut Pertanian Bogor, Bogor.

Juniarti, A.C., Supartono dan W. Nanik. 2017. Uji Aktivitas Antibakteri Sabun Cair Ekstrak Daun Jati (Tectona Grandis L.f). Indonesian Journal of Chemical Science. 6(1).

Lenny, S. 2006. Senyawa Flavonoida, Fenilpropanoida dan Alkaloid. Karya Ilmiah. Universitas Sumatera Utara, Medan

Luangmarumitchai S., S. Lamlertthon and W. Tiyaboonchai. 2007. Antimicrobial Activity of Essential Oil Against Five Strains of Propionibakterium acnes. Journal Pharmaceutical Science. 1(4): 60-64.

Naik M. I., B.A. Fomda. E., Jaykumar and J.A., Bhat. 2010. Antibacterial Activity of Lemongrass (Cymbopogon citratus) Oil Against Some Selected Pathogenic Bacterias. Asian Pasific Journal of Tropical Medicine. 535-538.

Karakteristik Mutu, Organoleptik Dan Aktivitas Antibakteri Sabun Padat Transparan Dengan Penambahan Minyak Serai Wangi (Cymbopogon nardus L) (Ova Ariska, Bahlina Mohd. Nur, Yuliani Aisyah)

Jurnal Ilmiah Mahasiswa Pertanian, Vol. 6, No. 1, Februari 2021: 27-36 
Novianty, T. J. 2017. Aplikasi Minyak Atsiri Serai Wangi (Cymbopogon nardus) Untuk Pengembangan Sabun Cair Pencuci Tangan. Skripsi. Fakultas Teknologi Pertanian. Institut Pertanian Bogor, Bogor.

Onawunmit, G.O., W.A.B. Yesiak and E.O. Ongulana. 1984. Antibacterial Constituent in the Essential Oil of Cymbopogon citratus. Journal Ethanopharmocol. 3(12): 279286.

Riska, M. 2013. Uji Aktivitas Antibakteri Minyak Atsiri Serai Wangi (Cymbopogon nardus L) Terhadap Isolat Klinis Staphylococcus aureus Secara In Vitro. Skripsi. Universitas Syiah Kuala, Banda Aceh.

Rohaeti Elly. 2018. Karakterisasi Sabun Transparan Pembersih Wajah Berbasis Kolagen Kulit Ikan Kakap Merah (Lutjanus sanguineus) Dan Kitosan. SKRIPSI. Institut Pertanian Bogor, Bogor

Simic, A., M. D. Sokovic dan Ristic, M. 2004. The Chemical Composition Of Some Lauraceace essential Oil and Their Antifungal Activities. Journal Pharmaceutical Biology. 18(2): 713-717

Standar Nasional Indonesia. 2016. Sabun Mandi Padat: No 06-3532-2016. Badan Standar Nasional, Jakarta.

SNI 01-2346-2006. 2006. Petunjuk Pengujian Organoleptik dan Sensori. Badan Standarisasi Nasional (BSN), Jakarta

Suprianto. 2008. Potensi Ekstrak Serai Wangi (Cymbopogon nardus L.) Sebagai Antibakteri Streptococcus mutans. Skripsi. Institut Pertanian Bogor, Bogor.

Paramita D.A.K., V.A. Akanade and I.B.W. Gunam. 2014. Inhibition Activity of Essential Oil of Lemongrass Leaves (Cymbopogon citratus) on the Growth of Eschericial coli, Staphylococcus aureus and Vibrio cholerae. Jurnal Rekayasa dan Manajemen Agroindustri. 2(1): 29-38.

Widyasanti, A., C. F. Listiarsi dan D. Rohdina. 2016. Pembuatan Sabun Padat Transparan Menggunakan Minyak Kelapa Sawit (Palm oil) Dengan Penambahan Bahan Aktif EkstrakTeh Putih (Camellia sinensis). Jurnal Teknik Pertanian. 5(3): 125136

Karakteristik Mutu, Organoleptik Dan Aktivitas Antibakteri Sabun Padat Transparan Dengan Penambahan Minyak Serai Wangi (Cymbopogon nardus L) (Ova Ariska, Bahlina Mohd. Nur, Yuliani Aisyah) 